\title{
Deterrence Theory in Paraguay: Exploring Fraud and Violation of Trust Cases
}

\author{
Andreas Schneider \\ Independent Researcher at Schneider Risk \& Business Consulting, 1849 Asuncion, Paraguay; me-andy@gmx.de \\ Received: 29 November 2018; Accepted: 2 January 2019; Published: 13 January 2019

\begin{abstract}
This research paper contributes to the literature of deterrence theory in general, and in particular, with respect to white-collar crime, offering valuable insight by using a unique dataset of fraud and violation of trust incidents within the jurisdiction of Paraguay. Descriptive evidence shows a clear and continuous misallocation of funds and human capital, therefore providing less efficient services for the public. Regression analysis suggests that clearance rate exerts a highly significant effect in deterring fraud, but the results are not clear for violation of trust incidents. Despite the limitations of available data, results confirm the deterrence theory in Paraguay. However, for more than two-thirds of victims, not even an attempt was made to seek justice. As a side-result, it seems that a soft-on-crime strategy, induced from the former German penal code, has led to an increasing share of pre-trial diversion, therefore enhancing white-collar crimes like fraud and violation of trust, due to impunity.
\end{abstract}

Keywords: deterrence; Paraguay; fraud; crime; soft on crime

\section{Introduction}

The deterrence concept focuses on the use or the threat of punishment with the intention to avoid people breaking the law that governs the coexistence of a society. These rule breakers, however, are almost on a daily basis being accused of fraud, violation of trust, embezzlement of public funds, and money laundering, among others, the main headlines in the newspapers. What it makes this so sensitive to society is the fact that these deviants are often politicians, prosecutors, judges, or other high-ranking public servants, who should be the first in line when it comes to maintaining law and order. This behavior, directly and indirectly, reduces the quality of life of all citizens, who must cope with the lack of resources for social, health, or educational programs (Fajnzylber et al. 2002; Oliver 2002). It offends and hurts collective feelings (Durkheim [1895] 1982), and thereby generate public anger and social unrest. High shares of pre-trial diversion (e.g., dismissals) and archiving cases have both reached more than 30 percent on average, and are enhancing typical white-collar crime incidents as fraud and violation of trust. More diversion by dismissals and archiving cases, or even ignoring charges made by victims, means that more time will be devoted to illegal activities (Entorf and Spengler 2008).

There is an increasing demand by the Paraguayan's civil society, non-government organizations, and multilateral lenders in promoting judicial and administrative reforms. It has been widely recognized that economic and social development requires democratic consolidation, respect for basic human rights, and a well-functioning judicial system (Dakolias 1999; World Bank 1998). While the judiciary is getting more and more unpredictable, solving cases in an unreasonable time frame with an increasing backlog of cases, they are not just affecting the efficiency of the judicial system, they are also affecting the fairness, access to justice, and even violating human rights (Dakolias 1999). However, to maximize the effect of deterrence, a combination of certainty, severity, and celerity are necessary, thereby creating an expected cost of committing a crime (Mendes and McDonald 2001). 
The aim of this paper is twofold: First, to shed light on the efficiency and the financial cost of Paraguay's judicial system, compared to other European countries to serve as a benchmark, chosen due to their similarities in population size, and the easy availability of data. Second, the paper contributes to the literature of deterrence theory, offering valuable insights by using exploratory regression analysis with data for fraud and violation of trust incidents within the jurisdiction of Paraguay.

After this introduction, a literature review analysis is made for different aspects and components of deterrence, followed by a short word about the Paraguayan Penal Code. In the next section, descriptive evidence of the efficiency of the judicial system is offered. Next, the results of the exploratory regression analysis for fraud and violation of trust are presented, before ending with a conclusion and recommendations.

\section{Literature Review}

Deterrence is grounded on the idea that offenders' decisions are based on a rational choice, taking into account expected payoffs of the criminal activity compared to legal income, personal tastes, and preferences, and the perceived likelihood of apprehension, conviction, and punishment (Becker 1968, 1993). There is a common consensus in the literature that deterrence is necessary for the maintenance of the legal system and the preservation of society. Its effectiveness depends upon the particular society in question (Ball 1955).

The effect of deterrence has been studied for a while from different perspectives and a variety of subfields in numerous countries around the globe, to assist in informing policymakers. Beccaria (1778, p. 100) argues that "crimes are more effectually prevented by the certainty, than the severity of punishment." However, deterrence requires the combination of certainty, severity, and celerity to work properly, and to generate an expected cost of committing a crime: (Mendes and McDonald 2001; Mendes 2004). Potential criminals combine these three elements before committing a crime, regardless of being risk-neutral, averse, or acceptant (Mendes 2004). However, it seems that there is still no consensus about the weights of each element in the equation. Grogger (1991) and Witte (1980), for instance, argue that increasing the certainty of a punishment has a larger deterrent effect than increasing severity, and they point also to the criminogenic effect of imprisonment.

Ball (1955, p. 351) argues that, in the first place, a law to have a deterrent effect depends upon the knowledge of a would-be offender of that law and its possible punishments, otherwise the law would have no deterrent effect at all. This communication process, or lack thereof, might result in different perceptions of the certainty and severity of punishment. "People are more influenced by their perceptions of the certainty of arrest if they believe the penalty if arrested would be sever [ ... ]" (Grasmick and Bryjak 1980, p. 486). Bailey and Lott (1976, p. 105) argue that the higher the level of perceived certainty, the higher the deterrent effect of severity. Hence, the perceived severity of the punishment may have a deterrent effect, because crime becomes more expensive. The reason that severity may be less effective could be in the fact that criminals and 'inspectors' may have inverse incentives, and therefore increasing severity would lead to less inspection, and less inspection to higher crime rates. This is especially true for less attractive crimes (Rauhut 2009).

Mastrobuoni and Rivers (2016) analyzed the data of Italian prisoners after a large collective pardon. They concluded "that low future time preference is a driver of criminal behavior" (p. 31). The same was concluded by Akerlund et al. (2016) after studying data for a Stockholm birth cohort at age 13. They aggregated that the link was much stronger for males with low intelligence. The ignorance of future consequences in favor of immediate benefits is one of six elements making up one's self-control in Gottfredson and Hirschi's (1990) A General Theory of Crime. They argue that low self-control is a driver to be more prone to criminal or deviant behavior, a behavior "of force or fraud taken in the pursuit of self-interest" (p. 15).

Time discounting is rarely taken into account in economic models; however, it has implications for deterrence- - the higher the individual discounting, the lower the deterrent effect for future punishment (Mastrobuoni and Rivers 2016). The fact that some criminals do not care much about the probability 
of incarceration may explain the weight of severity in the deterrence puzzle. Therefore, increasing severity may have a deterrent effect for low initial sentence length (Mastrobuoni and Rivers 2016). Increasing punishment certainty has direct effects on deterrence and incapacitation; on the other hand, increasing punishment severity has long-run effects on deterrence and incapacitation. In consequence, crime will decrease gradually to a new steady state, indicating that criminals respond to severity as well as certainty (Kessler and Levitt 1999). A slow justice system, however, runs in favor of offenders and potential offenders that discount time heavily. For them, the possible future costs of committing a crime are insufficient to deter in favor of an immediate benefit, because they do not feel the "pain of payment" at the moment of deviant behavior (Prelec and Loewenstein 1998). "The criminal law, as a long-distance danger, does not affect them" (von Hentig 1938, p. 559). Increasing a delay by one year, for example, would increase fraud cases by 11 percent in first-instance courts (Dalla Pellegrina 2007).

Personality traits seem to be particularly important indicators in the context of white-collar crime, such as fraud and violation of trust, which are the subjects of this paper. Low behavioral self-control, paired with high hedonism, low integrity, and high narcissism, are important variables to discriminate between white-collar offenders and non-offenders (Blickle et al. 2006).

Money, financial gain, and greed are the most common motives for white-collar offenders according to Bucy et al. (2008) who interviewed prosecutors, defense counsels, and white-collar offenders. Offenders, as a group, who participate in illegitimate activities, respond to incentives in much the same way as non-offenders who are engaged in legitimate activities (Ehrlich 1973). Wrong or even perverse incentives, like low penalties for abuse, poor accounting, and lax regulations will help to create environments for white-collar crime (Akerlof and Romer 1993; Black 2010). Ehrlich (1996) and Black (2010) go even further and argue that only prison sentences or sentencing guidelines shift the tax for crime, and can deter willful violations.

However, the consequences are not only of an economic nature. Despite the individual economic losses directly caused by the fraud itself, and indirectly caused by contracting a law firm and opportunity costs, there are also social consequences. Distrust or cynicism against the justice system or public institutions in general, or emotional consequences like anxiety disorder, major depressive episodes, or even suicidal tendencies are mentioned in the literature. White-collar crime can sometimes even involve physical harm from polluting the environment with toxic waste, unsafe working conditions, or from marketing unsafe products (Brody and Kiehl 2010; Friedrichs 2010; Ganzini et al. 1990; Malone 2010; Payne 2016; Pridmore and Reddy 2012; Seligson 2006). Sutherland (1940, p. 5) argues that "white-collar crimes violate trust and therefore create distrust, which produces social disorganization on a large scale." Nevertheless, a weak criminal justice system may increase risky attitudes, due to impunity, and push the perception of risk downward (Paternoster 2010).

\section{A Short Word about the Paraguayan Penal Code}

Rising crime rates of the 1970s were faced differently in Germany and most other European countries, and the US. While the latter followed a 'tough on crime strategy', Germany followed a softer path, bearing in mind future consequences for perpetrators-especially young deviants. The main aspect of the 'Grand reform' of 1969 was restricting the use of imprisonment in favor of non-custodial sentences like monetary fines. Another aspect was to strengthen the role of the public prosecutor in the context of pre-trial diversions (Cherry 2001; Entorf and Spengler 2008).

Paraguay's reform started in 1992 after 35 years of dictatorship, which ended in 1989. The new penal code became effective in 1997 (law no. 1160/97). It has been recognized that the new Paraguayan penal code is heavily based on the German penal code of 1969, which was still effective when Paraguay 
started its reform, and even "an almost textual and certainly quite unfortunate version of the Criminal Code in force in the Federal Republic of Germany" (Guzmán Dalbora 2008). ${ }^{1}$

German legislators were already working on a 'reform of the Grand Reform' with more severe maximum and minimum penalties for many violent crimes. The new law became effective in 1998 . This was the result of preceding discussions where apparently lenient sentences for violent crimes were criticized with respect to property crimes (Entorf and Spengler 2008). However, it seems that this historical fact combined with descriptive evidence presented in the following section may indicate the implementation of the German soft strategy into the Paraguayan penal code, without taking into account historical, cultural, and socio-economic differences. As a consequence, high and prevailing crime rates in general, and white-collar crime, in particular, might be the result of a soft-on-crime strategy, and an increasing share of pre-trial diversion, in particular, dismissals and archived cases, resulting in impunity.

Particularly, Latin American countries were a major concern for implementing human rights and re-democratizing the judicial system after decades of dictatorial control and abuses (Hammergren 2008). However, ideological ideas and psychological consequences are still present in some countries. While most European and even Latin American countries have already implemented new legal and administrative reforms, adjusting for new tendencies in crime, thereby fulfill their commitment to society and the social contract, Paraguay is still thinking about it.

\section{Data and Methods}

\subsection{Descriptive Evidence}

Due to a lack of previous research within the jurisdiction of Paraguay, some descriptive statistics are offered, and they put in an international context to shade some light about resources allocated, and efficiency of the judicial system. The usual standard measures for efficiency are the length of proceedings, the clearance rate, and case backlogs (European Union 2018, p. 10).

The following Table (Table 1) shows different professional groups who are involved in the judicial system, compared to the European median and three European countries, to serve as a benchmark, due to their similarities in population size, and the easy availability of data. It can be observed that figures of those who can clear a case, like judges and prosecutors, are below the European median, while lawyers, non-judge staff, and non-prosecutor staff exceed by far the figures that are reported for Denmark, Bulgaria, Serbia, and the European median. ${ }^{2}$ In particular, the high density of lawyers per 100,000 inhabitants and administrative staff should raise special attention to public policymakers. This points to a misallocation of human capital, and it probably indicates a low infrastructure regarding information technology.

Table 2 shows the budget spent to the judicial system. Paraguay outperforms Bulgaria, Serbia, and in most cases the European median, regarding the allocation of funds. ${ }^{3}$ Paraguayan's annual judiciary budget for 2012 was 1.81 percent of the GDP per capita and about three times higher than the budget of Bulgaria (0.54 percent) or even the European average, with 0.33 percent (World Bank 2015, p. 6). The budget available to the judicial system increased 12.47 percent, on average, between 2005 and 2017. The budget for the court increased 11.78 percent, and for the Public Ministry, 11.31 percent in the same period. Table 2 indicates a clear misallocation of funds with respect to the quality offered to society.

1 Wolfgang Schoene, a German specialist in penal law, has been mentioned by Guzman and in local newspapers (e.g., Ultima Hora, "La idea de una sumatoria de penas es absolutamente inconstitucional", 21 March 2010) as one of the designers, and he was heavily involved in the preparation of the new penal code.

2 Regular working hours in the judicial system are from 7:00 a.m. to 1:00 p.m. from Mondays to Fridays.

3 The Paraguayan judicial budget includes also the budget of the Superior Court of Electoral Justice, which has in most cases the same budget—or even more—as the Public Ministry. 
Table 1. Professionals per 100,000 inhabitants.

\begin{tabular}{cccccc}
\hline & Paraguay & Denmark & Bulgaria & Serbia & European Median \\
\hline Judges & $13.99(\mathrm{NA})$ & 6.00 & 30.80 & 38.00 & 18.06 \\
Prosecutors & $5.11(5.78)$ & 12.20 & 20.40 & 9.20 & 10.27 \\
Lawyers & $609.89(688.12)$ & 108.40 & 178.30 & 118.10 & 110.17 \\
Non-judge staff & $191.55 \times(\mathrm{NA})$ & 31.00 & 83.50 & 140.30 & 54.92 \\
Non-prosecutor staff & $64.49(64.80)$ & 8.10 & 40.50 & 16.80 & 14.13
\end{tabular}

Notes: All data for European countries from the European Commission for the Efficiency of Justice (CEPEJ) with 2014 as reference year; Judges' Data for Paraguay from Supreme court's official website with figures for 2017; Prosecutor data from the office of the Public Prosecutor (12 April and 24 May 2018) with data for 2014 (2017);

$\times$ indicates estimation (2018).

Table 2. Budget per inhabitant.

\begin{tabular}{cccccc}
\hline & \multicolumn{5}{c}{ Budget, EURO (€) per Inhabitant } \\
\hline & Paraguay & Denmark & Bulgaria & Serbia & European Median \\
\hline Judicial System & $57.47(62.47)$ & NA & 32.55 & NA & 46.40 \\
Court & $25.50(28.98)$ & 42.57 & 18.94 & 21.90 & 31.37 \\
Prosecution Servis & $13.42(14.34)$ & 17.16 & 13.01 & 5.00 & 9.21 \\
Legal Aid & $4.97(6.13)$ & NA & 0.60 & NA & 2.46 \\
\hline
\end{tabular}

Notes: All data for European countries from CEPEJ with 2014 as reference year; Data for Paraguay from the Ministry of Finance with reference year 2014 and recent data for 2017 in parentheses; Local currency Guaranies (Gs); $1 \mathrm{EUR}=6348 \mathrm{Gs}$ on average for 2017 and $1 \mathrm{EUR}=5924 \mathrm{Gs}$ on average for 2014; NA = Not available.

Despite the high and increasing budget allocations, Paraguayan's judiciary performance lags far behind European countries, as shown in Table 3. Overall clearance rate reached 52 percent in 2014, which is far below the European median.

Table 3. Efficiency of the judicial systems.

\begin{tabular}{cccccc}
\hline & \multicolumn{5}{c}{ Efficiency of the Judicial Systems per 100 Inhabitants } \\
\hline & Paraguay & Denmak & Bulgaria & Serbia & European Median \\
\hline Incoming cases & 2.77 & 2.35 & 1.92 & 10.60 & 1.22 \\
Resolved cases & 1.44 & 2.31 & 1.93 & 10.22 & 1.34 \\
Clearance rate \% & 52.0 & 98.5 & 100.5 & 96.5 & 99.9 \\
Pending cases & NA & 0.30 & 0.39 & 7.14 & 0.30 \\
Disposition time & NA & 47.00 & 74.00 & 255.00 & 112.00 \\
(days) & & & & &
\end{tabular}

Notes: All figures for 2014 and based on total criminal cases; Data for European countries from European Commission for the Efficiency of Justice (CEPEJ) indicating 1st instance for criminal cases; Data for Paraguay from the office of the Public Prosecutor's anual statistics report (online); NA = Not available.

The situation worsens when considering just fraud cases, the subject of this paper. Table 4 shows a clear and sharp decrease in clearance rate between 2001 and 2015, while the backlog is consequently increasing during the same period. ${ }^{4}$ At the end of 2015, the clearance rate was merely 12.73 percent, while it took more than six years for a pending case to be solved in the light of the current pace of work. However, increasing spending on personnel does not necessarily lead to reducing the disposition time (Buscaglia and Dakolias 1996). Of particular interest is the fact that, on average, more than two thirds (75.2\%) of the incoming cases between 2001 and 2015 do not have any procedural status. Expressed differently: to two-thirds of victims, not even an attempt was made to seek justice.

4 Recent data for the last eight years (2008-2015) are shown to illustrate the evolution of efficiency, however, data from 2001-2015 are available, and calculations are based on the entire series. See Table A5 in the appendix for part 1 (years 2001-2007). See Tables A6 and A7 in the appendix for the efficiency of violation of trust cases between 2001 and 2015. 
Table 4. Efficiency of the judicial system (fraud cases)—Part 2.

\begin{tabular}{ccccccccc}
\hline & $\mathbf{2 0 0 8}$ & $\mathbf{2 0 0 9}$ & $\mathbf{2 0 1 0}$ & $\mathbf{2 0 1 1}$ & $\mathbf{2 0 1 2}$ & $\mathbf{2 0 1 3}$ & $\mathbf{2 0 1 4}$ & $\mathbf{2 0 1 5}$ \\
\hline Incoming cases & 3884 & 4328 & 4315 & 5626 & 6145 & 5943 & 6749 & 6811 \\
Controlled cases & 940 & 1020 & 1345 & 1582 & 1500 & 1632 & 1663 & 1436 \\
Archived cases & 345 & 282 & 334 & 431 & 500 & 604 & 644 & 564 \\
Dismissals & 323 & 384 & 488 & 522 & 503 & 575 & 580 & 503 \\
Resolved cases & 593 & 741 & 1018 & 1156 & 1000 & 1024 & 1014 & 867 \\
Clearance rate \% & 15.27 & 17.13 & 23.60 & 20.54 & 16.27 & 17.23 & 15.02 & 12.73 \\
Backlog & 18,383 & 21,970 & 25,266 & 29,737 & 34,882 & 39,801 & 45,536 & 51,480 \\
Turnover ratio & 0.18 & 0.21 & 0.31 & 0.26 & 0.19 & 0.21 & 0.18 & 0.15 \\
Disposition time (days) & 2025.54 & 1766.05 & 1181.92 & 1411.68 & 1877.97 & 1752.97 & 2065.34 & 2502.87 \\
\hline
\end{tabular}

Notes: All figures correspond to fraud cases; Backlog is calculated since 2001; a controlled case is a case with an asigned procedural status (e.g., investigation, accused, desestimated etc.); Turnover ratio measures the relationship between resolved cases and unresolved cases at the end of a period; Disposition time (in days) measures the theoretical time necessary for a pending case to be solved in court in the light of the current pace of work.

The descriptive evidence shown above point to a clear misallocation of human capital and financial funds, which in turn, led to a less efficient system. Technical inefficiency (lag of best practice) and size inefficiency (courts are too big), account for more than 50 percent of total inefficiency in the justice sector (Peyrache and Zago 2016). This is a fertile ground for other serious crimes (i.e., corruption), or hamper democratic and economic development while one of society's core institution is not effective (Busso et al. 2012; Castelar Pinheiro 1996; Restuccia and Rogerson 2017).

\subsection{Dataset}

This study used yearly fraud and violation of trust incidents for a time span between 2001 and 2015, which accounted for more than 90 percent of crimes against property in the Paraguayan judicial system, and increased dramatically between 2000 and 2016 (Schneider 2018). This approach was preferred to avoid the aggregation bias of the (aggregated) crimes against property series used by Schneider (2018), which can result in a loss of information due to a considerable variation of the different crime types, each with different deterrent effects (Cherry and List 2002; Lee et al. 1990). No further distinctions were made regarding geography, age, gender, or race. These two dependent variables were subsequently related to the clearance rate, and further covariates mentioned in literature in a stepwise exploratory process due to sample size. Severity and celerity, as other deterrent components, were not included in the different regression specifications due to a lack of available data.

Certainty, as expressed by the clearance rate, was measured in percent and calculated as a ratio between the resolved cases to incoming cases at the end of a given period. The archived cases are a count variable at the end of a given period. Data were collected from the Public Ministry. The court budget and prosecution budget were measured in budget spending per inhabitant (in local currency unit), and calculated with data from the Ministry of Finance and the World Bank. Prosecutors is a count variable, and counts the absolute number of prosecutors in a given period. The unemployment rate indicates the official unemployment rate in percent (not accounting for sub-employment) in a given period. The Gross Domestic Product per capita growth rate (GDPpcgrate) as a measure of strength of a country's local income (within its borders), and the Gross National Income per capita growth rate (GNIpcgrate) as a measure of economic strength of the citizens of a country (including from local citizens living abroad) were included as regressors, and representing legal income opportunities. The descriptive statistics of offense-specific and socio-economic variables are offered in the Appendix (Tables A1 and A2).

\subsection{Exploratory Analysis}

Paraguay experienced an epidemic increase regarding white-collar crime incidents, particularly fraud and violation of trust, between 2000 and 2016, and they will remain on a high level (Schneider 
2018). In the following analysis mainly fraud data were presented; however, graphs and tables for the violation of trust data are offered in the appendix for reasons of space and convenience.

When a variable with a unit root is regressed on another variable with a unit root, this can lead to spurious regressions (Entorf 1997). Non-stationary data, as a rule, are unpredictable and therefore, most techniques require a stationary series to perform forecasts of relative or absolute nature. Different techniques were applied to transform the data and to smooth the different series, such as first and second order differences, as well as log-normal function. Subsequently, an Augmented Dickey Fuller Test (Dickey and Fuller 1979, 1981) and a KPSS Test (Kwiatkowski et al. 1992) were performed, with the aim to observe a more stationary dataset. As expected, stationarity could be assumed for the majority of the variables in first differences, except for the GDP per capita growth rate and the unemployment rate, which were stationary at level. Prosecutors count, court budget, and prosecution budget were stationary in second differences (Table A3). Furthermore, it could be assumed that crime market participants, in other words, criminal prosecution system and offenders, will need time to assimilate new information, and it therefore will create a time lag regarding their decision making. "[ ... ] humans are quite hesitant to adapt strategically to their social environment" (Rauhut 2009, p. 387). Likewise, recidivist offenders, motivated by low clearance rates and diversion, will contribute to crime rates in subsequent years. To account for this effect in the data generating process (DGP) a lagged dependent variable (LDV) $\mathrm{y}_{\mathrm{t}-1}$ was incorporated as an additional regressor. "However, in a dynamic equation where lagged values of the dependent variable appear as regressors, least squares estimates are biased and generally inconsistent" (Breusch 1978, p. 334). As suggested by Keele and Kelly (2005) a Lagrange Multiplier test was applied to test for the white noise of the residuals after introducing lagged dependent variables. Wilkins (2018) argues in a more recent research paper that more LDVs and lagged independent variables should be included, to account for autocorrelation, and provide more accurate coefficient estimates. Lagged-dependent variables also control for omitted variable bias (Mustard 2003), which in contrast, would seriously bias ordinary least squares regression coefficients.

Figures for fraud and violation of trust might be flawed by measurement errors, due to the fact that not all victims present charges. Coefficients for the clearance rate might be biased (ratio bias) for two reasons: (a) due to measurement errors of fraud and violation of trust incidents (cleared cases / registered cases), and (b) due to a high level of charges without any procedural status, which effects clearance rate. Furthermore, it depends on the offender to choose which type of crime to commit, which, in turn, influence the likelihood of being arrested and punished (Cook 1979). Coefficients for the clearance rate, however, might be understated, due to omitted variables of conviction rates and sentence length, due to a lack of data (Mustard 2003).

\subsubsection{Fraud}

The following graph (Figure 1) describes the evolution and persistence of fraud incidents reported to the Public Ministry between 2001 and 2015, indicating possible multiple breaks in the structure of the series. ${ }^{5}$ Chow tests that are applied to the series did not reveal statistically significant breaks for fraud (Table A4).

In a stepwise exploratory procedure, additional regressors are added, along with the clearance rate, as shown in Table 5. The incorporation of a LDV had benefited the intention to explore lasting effects, and they are in line with previous research (e.g., Buonanno and Montolio 2008; Caudill et al. 2013; Corman and Mocan 2000; Entorf and Spengler 2008; Imai and Krishna 2004; Mustard 2003; Oliver 2002). The lagged variable in the first and preferred regression specification was statistically significant. The negative sign indicates a reversion to an equilibrium $\left(\mathrm{y}_{\mathrm{t}}=\mathrm{y}_{\mathrm{t}-1}\right)$. Expressed differently: Offenders might change their behavior now if they know that they would receive a punishment in the future. However,

5 The expected sentence length for fraud is up to five years of prison or fine (Art. 187, Law No. 1160/97; Penal Code of Paraguay). 
the half-life or the degree of the mean reversion of a one-unit impulse was just eight months (0.809) (Kilian and Zha 1999). The high speed to mean reversion-or business as usual-seems to confirm that humans are quite hesitant to adapt to changes, but also indicates that the certainty element alone is not sufficient to deter deviants on the long-run. The clearance rate was highly significant and remarkably consistent at all different specifications, and they revealed a negative sign as expected according to theory. As expected, unemployment and archiving cases without the intention to prosecute and punish offenders will increase fraud in the future. Unexpectedly, for the GNI per capita growth rate, prosecution budget, and court budget, the sign was reversed. This phenomenon has already been reported by Achen (2000) who analyzed governmental budgets. He argues that incorporating lagged dependent variable coefficients dominate the regression, may induce autocorrelation, and diminish the effects of other covariates in the form of biased coefficients. Comparing regression one (1) and eight (8) might confirm this. Introducing a lagged dependent variable in a static process would be clearly a misspecification. However, the limit of the residual error due to stationarity should limit or reduce the remaining autocorrelation and any significant amount of bias. Furthermore, both exogenous budget variables were heavily trending and they were influenced by an unmeasured observation (probably internally driven by increasing funds for human resources), which might had caused the anomalous reverse of the expected sign (Achen 2000, p. 21). Therefore, if the DGP is dynamic, LDV models will provide better estimates (Keele and Kelly 2005). In this particular case of fraud incidents, the Breusch-Godfrey test did not reveal evidence for heteroskedasticity. It might be obvious that reversed signs and biased coefficients suffer from sample size, and with that a degree of freedom problem in the regression analysis, also due to transformation, which reduces the number of observations.

The direct impulse effects in model eight (8) are immediately evident from Table 5. Increasing the clearance rate by one percent would lead to a decrease of 4.3 percent, on average, in fraud incidents with a long-run effect of a 2.9 percent decline after a one-time impulse. On the other hand, archiving cases that do not serve to prosecute and clear a crime would lead to a direct increase of 30 percent with a long-run effect of 31 percent in fraud incidents. Increasing the number of prosecutors should have a negative effect on fraud, however, the coefficient is not significant. The estimate for unemployment was also not significant, but it indicates that a decrease in the unemployment rate might change the perception of people's future, and therefore, public policies regarding employment could reduce criminal behavior significantly (Imai and Krishna 2004). However, there was no evidence that economic variables do have a significant deterrent effect. In general, comparing additions in adjusted $\mathrm{R}^{2}$, it does not seem that substituting further control variables result in a significantly better prediction of fraud incidents. The preferred model one (1) already explains 70 percent of the variation, but also suggests that further deterrent elements like severity might increase the model fit.

\section{Possible Breakdates between 2001 and 2015 with $99 \%$ Confidence interval}

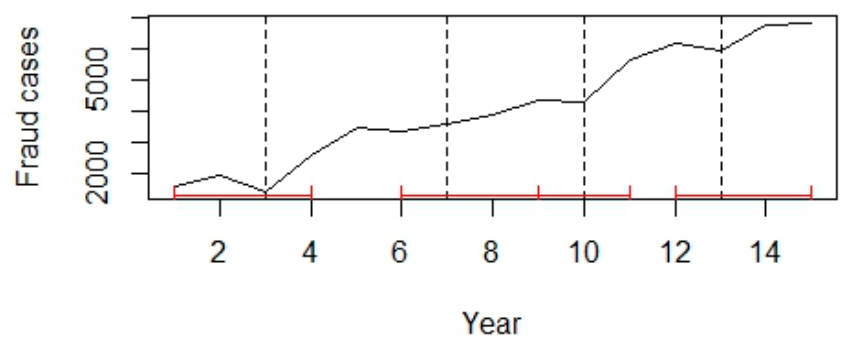

Figure 1. Possible break dates for fraud series. Data: Public Ministry. 
Table 5. Regression table for fraud incidents.

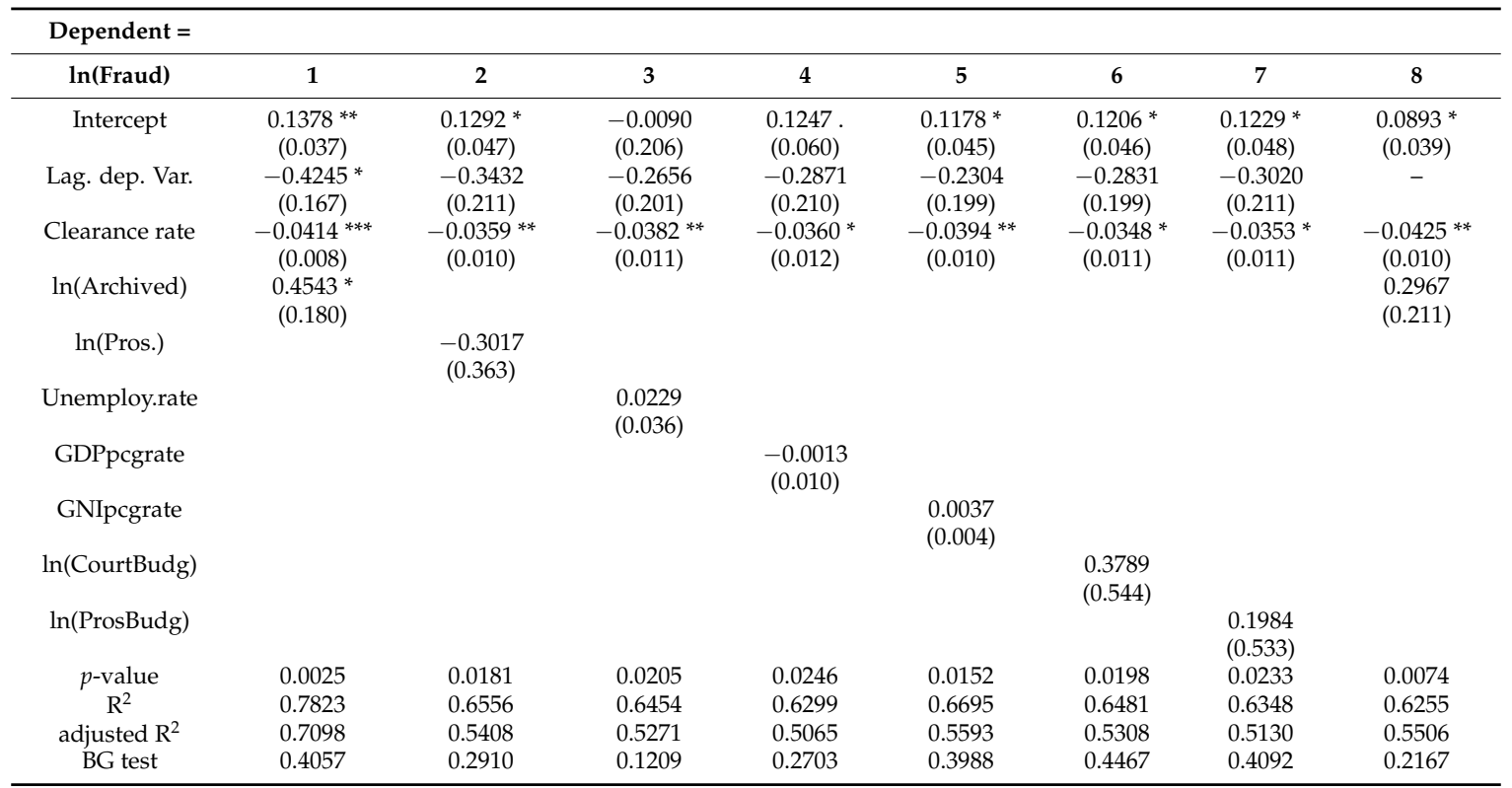

Notes: In addtion to the independent variable of interest (Clearance rate) different control variables were added in a stepwise process, $\ln$ indicates the natural logorhythm. Standard error in parentheses. Rates are given in \%. Budgets (per capita) are given in local currency. BG test $=p$-values for Breusch-Godfrey LM test at alpha $=0.05$. Signif. codes:

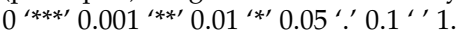

\subsubsection{Violation of Trust}

Figure 2 describes the evolution and persistence of violation of trust incidents between 2001 and 2015 , indicating possible multiple breaks in the structure of the series. ${ }^{6}$ Chow tests applied to the series revealed statistically significant breaks in 2003 and 2009, and which are probably due to unknown events or caused by a measurement error (Table A4).

\section{Possible Breakdates between 2001 and 2015 with $95 \%$ Confidence interval}

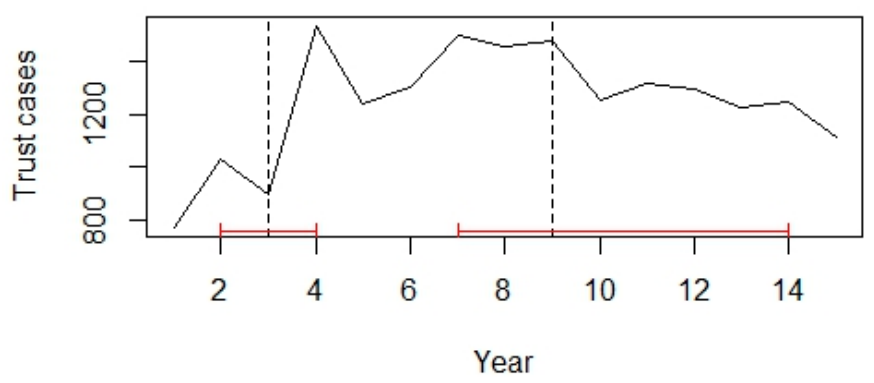

Figure 2. Possible break dates for violation of trust series. Data: Public Ministry.

Regression results for violation of trust incidents were not as obvious as for fraud. The sign for clearance rate, socio-economic, and budget variables was in line with theory, except for prosecutors who seemed to increase the incidents (Table 6). However, none of these variables had a significant effect. The clearance rate was significant on a generous 10 percent level in models three (3) and four (4), and significant on a 0.05 level in the static model. Introducing lagged-dependent variables had just a marginal effect and, as it seems, even induced autocorrelation (model three (3) and eight (8)), as

6 The expected sentence length for the violation of trust is up to five years, or a fine. In more severe cases, the sentence length can be up to 10 years (Art. 192, Law No. 1160/97; Penal Code of Paraguay). 
revealed by the Breusch-Godfrey test. A one unit change in the clearance rate would decline the violation of trust incidents by 2.4 percent in model eight (8). A one unit increase in the clearance rate would indicate a long-run effect of -1.8 percent, but with a half-life of just about eight months (0.850) in model three (3). Again, the results presented may suffer due to the small sample size. It might also be the case that most of the effects were already captured by fraud, because fraud and violation of trust often go together in real-world cases, and in particular with respect to white-collar crime incidents. This may indicate that the violation of trust is not necessarily a purposeful choice for a specific crime type, rather than a consequence or a by-product of deviant behavior (Durlauf et al. 2008).

Table 6. Regression table for the violation of trust incidents.

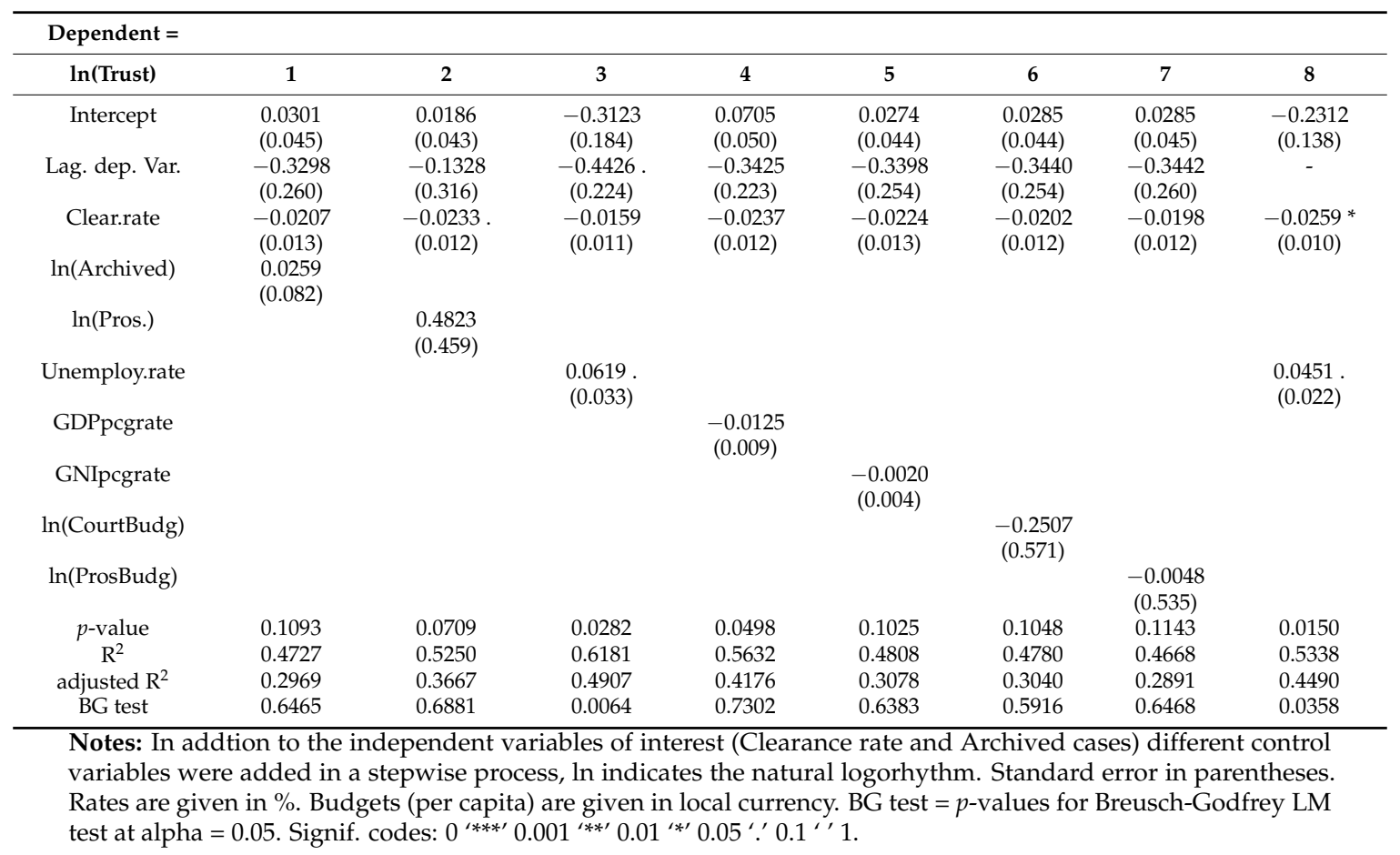

\section{Conclusions and Recommendations}

To the best of the author's knowledge, this paper comprises the first exploratory study of the deterrent effect of white-collar crimes within the jurisdiction of Paraguay. It also illustrated the efficiency of the Paraguayan judicial system.

The results have shown that a highly significant deterrent effect was exerted by increasing the clearance rate for fraud in all tested specifications, and with less significant relevance for violation of trust incidents. At least in the context of typical white-collar crimes like fraud and violation of trust incidents, certainty alone seems to deter possible offenders; however, with only a short-run effect. Deterrence to work properly-in the sense to maximize the combined effect-it requires certainty, severity, and celerity. Therefore, the combined effect of all three elements might be higher as reported (e.g., Mendes and McDonald 2001). Despite the limitations due to a lack of data, the exploratory results confirmed deterrence theory.

However, it is worth noting that this exploratory study did not depict the entire criminal prosecution process, which starts usually with police investigative work followed by public prosecution and ends with a sentence in court. In the particular case of white-collar crimes, the Public Ministry has to shoulder both investigation and prosecution within the jurisdiction of Paraguay.

In general, more legal income opportunities and better labor conditions may mitigate violent crimes by providing a more optimistic future perspective especially for young people (Entorf 2009; Fajnzylber et al. 2002; Witte and Tauchen 1994). In fact, juvenile misconduct today can imply 
tomorrow's crime (Buonanno and Montolio 2008). However, it does not seem that this might be the case in deterring fraud and violation of trust. This is probably due to the nature and motives of white-collar crime. Macroeconomic variables of Paraguay, generally associated as a mitigating factor of crime, were sound with an average GNI per capita growth rate of about 10.51 percent and an average GDP per capita growth rate of 2.47 percent over the same time period of this research.

It also seems that a soft on crime strategy was induced with the implementation of the new penal code based on a previous German version of 1969. Hence, high shares of dismissals, archiving cases and low sentences will continue to increase recidivism and encourage white-collar typical crimes like fraud and violation of trust. It should be noted that the offenses grouped here as white-collar crimes do not span the scale of offenses that can and should be regarded as a white-collar crime. For example, public corruption, embezzlement, tax evasion, money laundering, bankruptcy fraud, and bribery are notably absent.

As descriptive evidence revealed, the Paraguayan judicial system lacks efficiency rather than funding. "Governments allocate resources to criminal justice with little, or no, attention to outcome" (Spencer 1993, p. 7) and can be well predicted by last year's budget (Davis et al. 1966). However, different from the private sector where firms need to reduce costs to be competitive, the judicial system is a monopolist and the sole supplier of a specific public service. Short-term (mostly electoral) interests may expand the public sector, incorporating new employees (and voters) and thus re-enforcing the process of expenditure (Peacock 1978, pp. 120-21).

The vast majority of the victims depend on the expertise or good-will of the local prosecutor of the case despite the existence of a special unit which attends economic crimes and corruption (UDEA), but with limitations. ${ }^{7}$ To make better use of their technical knowledge, and offer a better service to society, its usage should be less restrictive. More generally, expertise and technical knowledge should be used as a driver to increase celerity for a timely punishment, and decrease significantly accumulated backlogs in different areas by implementing fast-track trials and special courts (e.g., Dalla Pellegrina 2007). This should also create best-practices to resolve special types of crime, and it should reduce incidents, not just for fraud and other white-collar crimes, enhancing victim satisfaction, and increasing public confidence (Cook et al. 2004; Peterson 2017). In general, as descriptive evidence revealed, the redistribution of funds and human capital should be a priority within the juridical system, to increase efficiency. This can be reached by increasing shares in information technology while reducing administrative staff, increasing connectivity with other government institutions, active management of case progress, and production of basic statistics on a routine and timely basis. The introduction of a police force with investigative tasks to relieve the investigative work of public prosecutors should also be considered.

Nevertheless, the data clearly indicates an epidemic problem. Therefore, conducting further empirical studies are recommended and required to better understand white-collar crime in Paraguay, and to help public policymakers to make better and more informed decisions.

Funding: No funding was received for this publication.

Conflicts of Interest: The author has no competing interest to declare.

$7 \quad$ UDEA = Unidad especializada en Delitos Económicos y Anticorrupción. The Unit has limitations, and is only able to act in the city of Asuncion (capital), passing a certain amount and if a public institution is a victim. In special cases, the attorney general can advise the special unit to investigate. 


\section{Appendix A. Descriptive Statistics of Offence-Specific Variables}

Table A1. Descriptive statistics of offence-specific variables.

\begin{tabular}{ccccc}
\hline & Mean & Std. dev & Min & Max \\
\hline Fraud & 4123 & 1807.90 & 1437 & 6811 \\
Clearance rate (\%) & 17.22 & 3.09 & 12.73 & 23.60 \\
Archived & 328.80 & 184.86 & 110 & 644 \\
Violantion of Trust & 1244 & 218.05 & 771 & 1535 \\
Clearance rate (\%) & 13.21 & 2.94 & 7.60 & 18.56 \\
Archived & 51.47 & 13.74 & 34 & 82 \\
\hline
\end{tabular}

Notes: Data are from the Office of the Public Prosecutor. All figures are given in absolute numbers except clearance rate.

\section{Appendix B. Descriptive Statistics of Socio-Economic Variables}

Table A2. Descriptive statistics of socio-economic variables.

\begin{tabular}{ccccc}
\hline & Mean & Std. dev & Min & Max \\
\hline Court Budget in Gs p. inhabitant & 84,478 & $44,898.51$ & 30,575 & 169,601 \\
Prosecution Budget in Gs p. inhabitant & 42,843 & $22,896.06$ & 16,396 & 86,307 \\
GDP per capita growth Rate & 2.47 & 4.85 & -5.23 & 12.51 \\
GNI per capita growth Rate & 10.51 & 7.27 & -4.79 & 20.87 \\
Unemployment Rate & 6.02 & 1.81 & 4.09 & 10.76 \\
Prosecutors & 296 & 50.59 & 218 & 372 \\
\hline
\end{tabular}

Notes: Budgets per inhabitant are given in local currency (Guaranies, Gs; 1 EUR = 6348 Gs; 2017 average). Growth rates are given in \%. Data from the Ministry of Finance, Central Bank, Office of the Public Prosecutor, UNESCO and World Bank.

\section{Appendix C. Unit Root and Stationarity Tests}

Table A3. Unit root and stationarity tests.

\begin{tabular}{|c|c|c|c|c|c|c|c|}
\hline & \multicolumn{4}{|c|}{ Unit Root Test } & \multicolumn{3}{|c|}{ Stationarity Test } \\
\hline & \multicolumn{3}{|c|}{ ADF Test } & \multirow[b]{2}{*}{ 2.diff } & \multicolumn{3}{|c|}{ KPSS Test } \\
\hline & level & $\log$ & 1.diff & & level & $\log$ & 1. diff \\
\hline $\ln$ (Fraud) & 2.222 & 2.052 & $-2.046^{*}$ & & $0.062 *$ & $0.122 *$ & \\
\hline $\ln$ (Trust) & 0.201 & & $-2.256^{*}$ & & 0.199 & & 0.102 ** \\
\hline $\ln ($ Arch $)$ & 0.082 & 1.173 & -1.630 & $-2.450 *$ & $0.088^{* *}$ & $0.092^{* *}$ & \\
\hline Clear.rate & -0.463 & & $-3.987^{* *}$ & & $0.085^{*}$ & & \\
\hline $\ln$ (Pros.) & 2.183 & 2.347 & -1.749 & $-6.733 * *$ & 0.148 & 0.168 . & $0.089 * *$ \\
\hline GDPpcgRate & $-2.061 *$ & & & & $0.068^{* *}$ & & \\
\hline GNIpcgRate & -1.300 & & $-7.058^{* *}$ & & $0.075^{* *}$ & & \\
\hline Unemploy.rate & $-3.669 * *$ & & & & $0.137^{* *}$ & & \\
\hline $\ln ($ CourtBudg) & 2.655 & 2.631 & & $-3.941^{* *}$ & 0.203 & $0.057^{* *}$ & \\
\hline $\ln$ (ProsBudg) & 2.641 & 2.646 & & $-2.841^{* *}$ & 0.199 . & $0.096^{* *}$ & \\
\hline
\end{tabular}

Notes: $p$-values are reported until ADF and KPSS tests indicate stationarity at $p<0.05$. $\ln$ indicates the natural

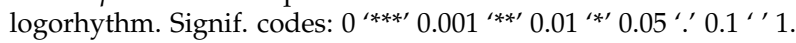




\section{Appendix D. Chow Tests}

Table A4. Chow tests for fraud and violation of trust series.

\begin{tabular}{cccccc}
\hline & \multicolumn{5}{c}{ Chow Tests for Possible Breaks } \\
\cline { 2 - 6 } & $\mathbf{2 0 0 3}$ & $\mathbf{2 0 0 7}$ & $\mathbf{2 0 0 9}$ & $\mathbf{2 0 1 0}$ & $\mathbf{2 0 1 3}$ \\
\hline Fraud & 2.0560 & 0.5884 & - & 0.3904 & 0.0090 \\
Violation of trust & $(4.9646)$ & $(4.1203)$ & - & $(6.0942)$ & $(241.8817)$ \\
& 19.2117 & - & 9.0862 & - & - \\
& $(4.9646)$ & - & $(6.0942)$ & - & - \\
\hline
\end{tabular}

Notes: Coefficients for fraud are on a $99 \%$ level and for violation of trust on $95 \%$ level. Critical values in parentheses. $\mathrm{H} 0=$ no breaks. Based on data from the Public Ministry.

\section{Appendix E. Efficiency of the Judicial System (Fraud Cases-Part 1}

Table A5. Efficiency of the judicial system (fraud cases)-Part 1.

\begin{tabular}{cccccccc}
\hline & $\mathbf{2 0 0 1}$ & $\mathbf{2 0 0 2}$ & $\mathbf{2 0 0 3}$ & $\mathbf{2 0 0 4}$ & $\mathbf{2 0 0 5}$ & $\mathbf{2 0 0 6}$ & $\mathbf{2 0 0 7}$ \\
\hline Incoming cases & 1589 & 1971 & 1437 & 2637 & 3494 & 3375 & 3604 \\
Controlled cases & 401 & 408 & 446 & 579 & 705 & 750 & 944 \\
Archived cases & 115 & 110 & 116 & 123 & 189 & 259 & 316 \\
Dismissals & 151 & 132 & 139 & 210 & 236 & 216 & 320 \\
Resolved cases & 287 & 300 & 331 & 460 & 519 & 490 & 628 \\
Clearance rate \% & 18.09 & 15.20 & 23.06 & 17.44 & 14.85 & 14.52 & 17.42 \\
Backlog & 1302 & 2973 & 4079 & 6256 & 9231 & 12,116 & 15,092 \\
Turnover ratio & 0.22 & 0.18 & 0.30 & 0.21 & 0.17 & 0.17 & 0.21 \\
Disposition time (days) & 1652.78 & 2036.73 & 1218.12 & 1727.85 & 2092.71 & 2148.22 & 1730.27 \\
\hline
\end{tabular}

Notes: All figures correspond to fraud cases; Backlog is calculated since 2001; a controlled case is a case with an asigned procedural status (e.g., investigation, accused, desestimated etc.); Turnover ratio measures the relationship between resolved cases and unresolved cases at the end of a period; Disposition time (in days) measures the theoretical time necessary for a pending case to be solved in court in the light of the current pace of work.

\section{Appendix F. Efficiency of the Judicial System (Violation of Trust Cases)—Part 1}

Table A6. Efficiency of the judicial system (violation of trust cases)—Part 1.

\begin{tabular}{cccccccc}
\hline \multicolumn{8}{c}{ Efficiency of the Paraguayan Judicial System (Violation of Trust Cases)_Part 1 } \\
\hline & $\mathbf{2 0 0 1}$ & $\mathbf{2 0 0 2}$ & $\mathbf{2 0 0 3}$ & $\mathbf{2 0 0 4}$ & $\mathbf{2 0 0 5}$ & $\mathbf{2 0 0 6}$ & $\mathbf{2 0 0 7}$ \\
\hline Incoming cases & 771 & 1028 & 898 & 1535 & 1241 & 1303 & 1494 \\
Controlled cases & 155 & 195 & 206 & 227 & 244 & 276 & 191 \\
Archived cases & 34 & 48 & 49 & 44 & 51 & 82 & 51 \\
Dismissals & 49 & 73 & 76 & 103 & 90 & 106 & 73 \\
Resolved cases & 105 & 125 & 133 & 156 & 167 & 165 & 113 \\
Clearance rate \% & 13.64 & 12.12 & 14.80 & 10.19 & 13.49 & 12.64 & 7.60 \\
Backlog & 666 & 1569 & 2334 & 3713 & 4787 & 5925 & 7305 \\
Turnover ratio & 0.16 & 0.14 & 0.17 & 0.11 & 0.16 & 0.14 & 0.08 \\
Disposition time (days) & 2310.48 & 2647.39 & 2101.98 & 3217.54 & 2339.87 & 2522.74 & 4440.04 \\
\hline
\end{tabular}

Notes: All figures correspond to violation of trust cases; Backlog is calculated since 2001; a controlled case is a case with an asigned procedural status (e.g., investigation, accused, desestimated etc.); Turnover ratio measures the relationship between resolved cases and unresolved cases at the end of a period; Disposition time (in days) measures the theoretical time necessary for a pending case to be solved in court in the light of the current pace of work. 


\section{Appendix G. Efficiency of the Judicial System (Violation of Trust Cases)—Part 2}

Table A7. Efficiency of the judicial system (violation of trust cases)—Part 2.

\begin{tabular}{ccccccccc}
\hline \multicolumn{7}{c}{ Efficiency of the Paraguayan Judicial System (Violation of Trust Cases)_Part 2 } \\
\hline & $\mathbf{2 0 0 8}$ & $\mathbf{2 0 0 9}$ & $\mathbf{2 0 1 0}$ & $\mathbf{2 0 1 1}$ & $\mathbf{2 0 1 2}$ & $\mathbf{2 0 1 3}$ & $\mathbf{2 0 1 4}$ & $\mathbf{2 0 1 5}$ \\
\hline Incoming cases & $14 \mathrm{~s} 55$ & 1477 & 1256 & 1314 & 1298 & 1224 & 1248 & 1111 \\
Controlled cases & 229 & 374 & 295 & 235 & 242 & 262 & 238 & 289 \\
Archived cases & 43 & 71 & 38 & 44 & 52 & 70 & 59 & 36 \\
Dismissals & 93 & 173 & 136 & 77 & 73 & 86 & 66 & 67 \\
Resolved cases & 159 & 256 & 223 & 154 & 162 & 162 & 145 & 206 \\
Clearance rate \% & 10.94 & 17.33 & 17.74 & 11.69 & 12.48 & 13.23 & 11.64 & 18.56 \\
Backlog & 8601 & 9822 & 10,855 & 12,016 & 13,152 & 14,214 & 15,317 & 16,221 \\
Turnover ratio & 0.12 & 0.21 & 0.22 & 0.13 & 0.14 & 0.15 & 0.13 & 0.23 \\
Disposition time (days) & 2971.77 & 1740.57 & 1692.43 & 2757.00 & 2560.83 & 2394.03 & 2769.63 & 1601.47 \\
\hline
\end{tabular}

Notes: All figures correspond to violation of trust cases; Backlog is calculated since 2001; a controlled case is a case with an asigned procedural status (e.g., investigation, accused, desestimated etc.); Turnover ratio measures the relationship between resolved cases and unresolved cases at the end of a period; Disposition time (in days) measures the theoretical time necessary for a pending case to be solved in court in the light of the current pace of work.

\section{References}

Achen, Christopher H. 2000. Why lagged dependent variables can suppress the explanatory power of other independent variables. Paper presented at the Annual Meeting of the Political Methodology Section of the American Political Science Association at UCLA, Los Angeles, CA, USA, July 20-22.

Akerlof, George A., and Paul M. Romer. 1993. Looting: The economic underworld of bankruptcy for Profit. Brookings Papers on Economic Activity 2: 1-73. [CrossRef]

Akerlund, David, Bart H. H. Golsteyn, Hans Groenqvist, and Lena Lindahl. 2016. Time discounting and criminal behavior. Proceedings of the National Academy of Sciences of the United States of America 113: 6160-65. [CrossRef] [PubMed]

Bailey, William C., and Ruth P. Lott. 1976. Crime, punishment and personality: An examination of the deterrence question. Journal of Criminal Law and Criminology 67: 99-109. [CrossRef]

Ball, John C. 1955. Deterrence concept in criminology and law. Journal of Criminal Law, Criminology E Police Science 46: 347-54.

Beccaria, Cesare B. 1778. An Essay on Crimes and Punishments. By the Marquis Beccaria of Milan with a commentary by M. de Voltaire. Edinburgh: Donaldson.

Becker, Gary S. 1968. Crime and Punishment: An economic approach. Journal of Political Economy 76: 169-217. [CrossRef]

Becker, Gary S. 1993. Nobel Lecture: The economic way of looking at behavior. Journal of Political Economy 101: 385-409. [CrossRef]

Black, William K. 2010. Wall St. Fraud and Fiduciary Responsibilities: Can Jail Time Serves as an Adequate Deterrent for Willful Violations? Testimony of William K. Black before the U.S. Senate, Committee on the Judiciary, Subcommittee on Crime and Drugs. Available online: https:/ / papers.ssrn.com/sol3/papers.cfm? abstract.id=1607045 (accessed on 18 October 2017).

Blickle, Gerhard, Alexander Schlegel, Pantaleon Fassbender, and Uwe Klein. 2006. Some personality correlates of business white-collar crime. Applied Psychology: An International Review 55: 220-33. [CrossRef]

Brody, Richard G., and Kent A. Kiehl. 2010. From white-collar crime to red-collar crime. Journal of Financial Crime 17: 351-64. [CrossRef]

Breusch, Trevor S. 1978. Testing for autocorrelation in dynamic linear models. Australian Economic Papers 17: 334-55. [CrossRef]

Bucy, Pamela H., Elizabeth P. Formby, Marc S. Raspanti, and Kathryn E. Rooney. 2008. Why do they do it? The Motives, mores, and character of white collar criminals. St. Johns Law Review 82: 401-572.

Buonanno, Paolo, and Daniel Montolio. 2008. Identifying the socio-economic and demographic determinants of crime across Spanish provinces. International Review of Law and Economics 28: 89-97. [CrossRef] 
Buscaglia, Edgardo, and Maria Dakolias. 1996. Judicial Reform in Latin American Courts. The Experience in Argentina and Ecuador. World Bank Technical Paper No. 350. Washington, DC: World Bank.

Busso, Matias, Lucia Madrigal, and Carmen Pages. 2012. Productivity and Resource Misallocation in Latin America. IDB-WP-306. Washington, DC: Inter-American Development Bank.

Castelar Pinheiro, Armando. 1996. Judicial system performance and economic development. Paper presented for the Seminar Economic Growth, Institutional Quality and the Role of the Judicial Institutions, IRIS, Washington, DC, USA, December 5-6.

Caudill, Jonathan W., Ryan Getty, Rick Smith, Ryan Patten, and Chad R. Trulson. 2013. Discouraging window breakers: The lagged effects of police activity on crime. Journal of Criminal Justice 41: 18-23. [CrossRef]

Cherry, Todd L. 2001. Financial penalties as an alternative criminal sanction: Evidence from panel data. Atlantic Economic Journal 29: 450-58. [CrossRef]

Cherry, Todd L., and John A. List. 2002. Aggregation bias in the economic model of crime. Economics Letter 75: 81-86. [CrossRef]

Cook, Philip J. 1979. Clearance rate as a measure of criminal justice system effectiveness. Journal of Public Economics 11: 135-42. [CrossRef]

Cook, Dee, Mandy Burton, Amanda Robinson, and Christine Vallely. 2004. Evaluation of Specialist Domestic Violence Courts/Fast-Track Systems. London: Crown Prosecution Service.

Corman, Hope, and H. Naci Mocan. 2000. A time-series analysis of crime, deterrence, and drug abuse in New York City. American Economic Review 90: 584-604. [CrossRef]

Dakolias, Maria. 1999. Court performance around the world: A comparative perspective. Yale Human Rights and Development Journal 2: 87-142.

Dalla Pellegrina, Lucia. 2007. Courts delays and crime deterrence. (An application to crimes against property in Italy). European Journal of Law and Economics 26: 267-90. [CrossRef]

Davis, Otto A., Michael Alan Howarth Dempster, and Aaron Wildavski. 1966. A theory of the budgetary process. The American Political Science Review 60: 529-47. [CrossRef]

Dickey, David A., and Wayne A. Fuller. 1979. Distributions of the estimators for autoregressive time series with a unit root. Journal of the American Statistical Association 74: 427-31.

Dickey, David A., and Wayne A. Fuller. 1981. Likelihood ratio statistics for autoregressive time series with a unit root. Econometrica 49: 1057-72. [CrossRef]

Durkheim, Emile. 1982. The Rules of Sociological Method. Edited by Steven Lukes. New York: The Free Press. First published 1895.

Durlauf, Steven N., Salvador Navarro, and David A. Rivers. 2008. On the Interpretation of Aggregate Crime Regressions. In Crime Trends. Edited by Arthur S. Goldberger and Richard Rosenfeld. Washington, DC: National Academy of Sciences Press.

Ehrlich, Isaac. 1973. Participation in illegitimate activities: A theoretical and empirical investigation. The Journal of Political Economy 81: 521-65. [CrossRef]

Ehrlich, Isaac. 1996. Crime, punishment and the market of offenses. Journal of Economic Perspectives 10: $43-67$. [CrossRef]

Entorf, Horst. 1997. Random walks with drifts: Nonsense regression and spurious fixed-effect estimation. Journal of Econometrics 80: 287-96. [CrossRef]

Entorf, Horst, and Hannes Spengler. 2008. Is Being 'Soft on Crime' the Solution to Rising Crime Rates? Evidence from Germany. IZA Discussion Paper No. 3710. Bonn: Institute for the Study of Labor.

Entorf, Horst. 2009. Crime and the Labour Market: Evidence from a Survey of Inmates. IZA Discussion Paper No. 3976. Bonn: Institute for the Study of Labor.

European Union. 2018. The 2018 EU Justice Scoreboard. Luxembourg: European Union.

Fajnzylber, Pablo, Daniel Lederman, and Norman Loayza. 2002. What causes violent crime? European Economic Review 46: 1323-57. [CrossRef]

Friedrichs, David O. 2010. Trusted Criminals. White Collar Crime in Contemporary Society, 4th ed. Belmont: Wadsworth Cengage Learning.

Ganzini, Linda, Bentson McFarland, and Joseph Bloom. 1990. Victims of fraud: Comparing victims of white collar crime and violent crime. The Bulletin of the American Academy of Psychiatry and the Law 18: 55-63. [PubMed]

Gottfredson, Michael R., and Travis Hirschi. 1990. A General Theory of Crime. Stanford: Stanford University Press. 
Grasmick, Harold G., and George J. Bryjak. 1980. The deterrent effect of perceived severity of punishment. Social Forces 59: 471-91. [CrossRef]

Grogger, Jeffrey. 1991. Certainty vs. severity of punishment. Economic Inquiry 29: 297-309. [CrossRef]

Guzmán Dalbora, José Luis. 2008. El nuevo código penal del Paraguay (1997). Available online: https: / / www. unifr.ch/ddp1/derechopenal/articulos/a_20080521_95.pdf (accessed on 25 September 2018).

Hammergren, Linn. 2008. Twenty-five years of Latin American judicial reforms: Achievements, disappointments, and emerging issues. The Whitehead Journal of Diplomacy and International Relations 9: 89-104.

Imai, Susumu, and Kala Krishna. 2004. Employment, dynamic deterrence and crime. International Economic Review 45: 845-72. [CrossRef]

Keele, Luke, and Nathan J. Kelly. 2005. Dynamic models for dynamic theories: The ins and outs of lagged dependent variables. Political Analysis 14: 186-205. [CrossRef]

Kessler, Daniel, and Steven D. Levitt. 1999. Using sentence enhancements to distinguish between deterrence and incapacitation. Journal of Law and Economics 42: 343-63. [CrossRef]

Kilian, Lutz, and Tao Zha. 1999. Quantifying the Half-Life of Deviations from PPP: The Role of Economic Priors. FRB Atlanta Working Paper Series No. 99-21. Atlanta: Federal Reserve Bank.

Kwiatkowski, Denis, Peter C. B. Phillips, Peter Schmidt, and Yongcheol Shin. 1992. Testing the null hypothesis of stationarity against the alternative of a unit root. How sure are we that economic times series have a unit root? Journal of Econometrics 54: 159-78. [CrossRef]

Lee, Kevin C., M. Hashem Pesaran, and Richard G. Pierse. 1990. Testing for aggregation bias in linear model. Economic Journal 100: 137-50. [CrossRef]

Malone, Mary Fran T. 2010. The verdict is in: The impact of crime on public trust in Central American justice systems. Journal of Politics in Latin America 2: 99-128.

Mastrobuoni, Giovanni, and David A. Rivers. 2016. Criminal Discount Factors and Deterrence. IZA Discussion Paper No. 9769. Bonn: Institute for the Study of Labor.

Mendes, Silvia M., and Michael D. McDonald. 2001. Putting severity of punishment back in the deterrence package. Policy Studies Journal 29: 558-610. [CrossRef]

Mendes, Silvia M. 2004. Certainty, Severity, and Their Relative Deterrent Effects: Questioning the Implications of the Role of Risk in Criminal Deterrence Policy. Policy Studies Journal 32: 59-74. [CrossRef]

Mustard, David B. 2003. Reexamining criminal behavior: The importance of omitted variable bias. The Review of Economics and Statistics 85: 205-11. [CrossRef]

Oliver, Alison. 2002. The economics of crime: An analysis of crime rates in America. The Park Place Economist 10: 30-35.

Paternoster, Raymond. 2010. How much do we really know about criminal deterrence? Journal of Criminal Law and Criminology 100: 765-823.

Payne, Brian K. 2016. White Collar Crime: The Essentials, 2nd ed. Thousand Oaks: SAGE.

Peacock, Alan T. 1978. The economics of bureaucracy: An inside view. The Economics of Politics 18: 117-31.

Peterson, Vandana. 2017. Speeding up sexual assault trials: A constructive critique of India's fast-track courts. Yale Human Rights and Development Journal 18: 59-109.

Peyrache, Antonio, and Ángelo Zago. 2016. Large courts, small justice! The inefficiency and the optimal structure of the Italian justice sector. Omega 64: 42-56. [CrossRef]

Prelec, Drazen, and George Loewenstein. 1998. The red and the black: Mental accounting of savings and debt. Marketing Science 17: 4-28. [CrossRef]

Pridmore, Saxby, and Anil Reddy. 2012. Financial loss and suicide. The Malaysian Journal of Medical Sciences 19: 74-76. [PubMed]

Rauhut, Heiko. 2009. Higher punishment, less control? Experimental evidence on the inspection game. Rationality and Society 21: 359-92. [CrossRef]

Restuccia, Diego, and Richard Rogerson. 2017. The causes and costs of misallocation. Journal of Economic Perspectives 31: 151-74. [CrossRef]

Seligson, Mitchell A. 2006. The measurement and impact of corruption victimization: Survey evidence from Latin America. World Development 34: 381-404. [CrossRef]

Schneider, Andreas. 2018. Are their collars still white? White-collar crime: Evidence from Paraguay 2000-2016. Innovative Issues and Approaches in Social Sciences 11: 116-37. [CrossRef] 
Spencer, Jon. 1993. Criminal justice expenditure: A global perspective. The Howard Journal of Crime and Justice 32: 1-11. [CrossRef]

Sutherland, Edwin H. 1940. White collar criminality. American Sociological Review 5: 1-12. [CrossRef]

von Hentig, Hans. 1938. Limit of deterrence. American Institute of Criminal Law and Criminology 29: 555-61. [CrossRef]

Wilkins, Arjun S. 2018. To lag or not to lag? Re-evaluating the use of lagged dependent variables in regression analysis. Political Science Research and Methods 6: 393-411. [CrossRef]

Witte, Ann Dryden. 1980. Estimating the economic model of crime with individual data. Quarterly Journal of Economics 91: 57-84. [CrossRef]

Witte, Ann Dryden, and Helen Tauchen. 1994. Work and Crime: An Exploration Using Panel Data. NBER Working Paper No. 4794. Cambridge: National Bureau of Economic Research.

World Bank. 1998. Development and Human Rights: The Role of the World Bank. Washington: World Bank.

World Bank. 2015. Bulgaria. Judicial Performance, Caseload and Expenditure Review (2008-2014). Washington: World Bank.

(c) 2019 by the author. Licensee MDPI, Basel, Switzerland. This article is an open access article distributed under the terms and conditions of the Creative Commons Attribution (CC BY) license (http://creativecommons.org/licenses/by/4.0/). 